\title{
Entry, Exit and Innovation over the Industry Life Cycle in Converging Sectors: An Analysis of the Smartphone Industry
}

\author{
Paolo Calvosa ${ }^{1}$ \\ ${ }^{1}$ Department of Economics, Management, Institutions (DEMI), University of Naples Federico II, Naples, Italy \\ Correspondence: Paolo Calvosa, Department of Economics, Management, Institutions (DEMI), University of \\ Naples Federico II, Campus Monte S. Angelo, Via Cinthia 26, 80126, Naples, Italy. E-mail: calvosa@unina.it
}

Received: November 9, 2020

Accepted: November 23, 2020

Online Published: November 24, 2020

doi:10.5539/ijbm.v15n12p151

URL: https://doi.org/10.5539/ijbm.v15n12p151

\begin{abstract}
This paper examines the digital convergence process that led to the development of the smartphone sector and the dynamics of entry, exit and innovation over the industry life cycle. We have verified, by a historical-longitudinal study, if several empirical regularities that characterize the evolution of firms and industries over time have distinguished also an industry born from a sectoral convergence process. From the analysis it emerged that the evolution of market sales and of product innovation in the smartphone industry, as well as firms entry and exit dynamics, are consistent with the evolutionary model identified by technology management and industry life cycle studies. It has also been found that the convergence process has favored the entry and the survival of new entrants, compared to the incumbent firms, coming from the native converging sectors - that of Personal digital assistants and of Mobile (feature) phones - from which the smartphone industry originated.
\end{abstract}

Keywords: industry convergence, industry life cycle, entry and exit, innovation processes, smartphones

\section{Introduction}

It is now generally recognized in the academic literature that the structural and competitive characteristics of industries vary over time. The results of numerous empirical studies have shown here that the sectors tend mainly to evolve following a life cycle characterized by a series of empirical regularities concerning how entry, exit, market structure, and technological change vary from the birth of industries through to maturity (Klepper, 1996). A full understanding of the mechanisms underlying the evolutionary dynamics at the sectoral level require the use of different study perspectives, which provided complementary reading keys. Over time, we have witnessed a strong rapprochement between research on the subject carried out in the field of evolutionary economics (Nelson \& Winter, 1982; Gort \& Klepper, 1982; Klepper, 1996, 1997) and technology management studies (Abernathy, 1978; Abernathy \& Utterback, 1978; Utterback \& Suarez, 1993; Tushman \& Anderson, 1986, Anderson \& Tushman, 1990; Audretsch, 1991, 1995, 1997). Although there are some interpretative differences between the two perspectives, especially as regards to the notion of dominant design (Klepper, 1996; Klepper \& Simon, 1996), their integrated use has allowed us to understand that the typology of knowledge and skills that fuel the industrial innovation processes influence in a decisive way the evolution of the industrial demography and of the sectoral competitive dynamics (Breschi, Malerba, \& Orsenigo, 2000; Agarwal, Sarkar, \& Echambadi, 2002; Garavaglia, 2004). It is in particular with the introduction of the concept of 'industry technological regime' (Nelson \& Winter, 1982) - which refers to the knowledge environment in which firms operate - that firmly states in the literature an evolutionary model based on the idea that the specific pattern of innovative activities in an industry are closely related to the generational processes of variety and selection.

Precisely linked to the theoretical approach of technological regimes, Anderson and Thusman (1986; 1990), based on the examination of various industries, propose an evolutionary model of technological change that allows the interpretation of the industry evolution on the basis of 'technological discontinuities' which occur over time. In particular they describe the different effects that two types of technological discontinuities (competence-destroying and competence-enhancing) may have on changes in industrial structures. Always starting from the assumptions underlying the evolutionary model of technological regimes, Audretsch (1995, 1997) considers that the arrangements in which firms and industries tend to evolve depend on differences in knowledge conditions and technology that underlie the specific industry. The scholar, however, extends its 
interpretative value highlighting that the dynamic patterns of firms may vary not only over time, but also from industry to industry, in relation to the different technological opportunities that occur at the sectoral level. Starting from these studies, further analysis has been carried out that have deepened the examination of how technological cycles condition the form and level of competition, the attractiveness of entry and industry structures (among the others: Agarwal et al., 2002; Dinlersoz \& MacDonald, 2009; Bos, Economidou, \& Sanders, 2013).

The results of the research that has studied the relationship between innovation and industrial evolution over time have indirectly provided new interpretative keys to shed light on one of the main sectoral transformation events on which in recent years has been focusing the attention of the studies in the managerial economic field. This refers to the phenomenon of industrial convergence, which has led to the confluence and merging of many separate markets, especially in digital sectors (Yoffie, 1997). The convergence processes have in fact determined significant breaks in production and technological architecture in many areas, often causing a redefinition of the structural characteristics of the converging sectors and, therefore, of the relative industry life cycle curves (Hacklin, Marxt, \& Fahrni, 2009; Lind, 2005). It was observed in this respect that the technological and market changes that characterize the sectors affected by convergence processes make sure that the industry life cycle curves of these sectors "form an entangled dimensional space of mutual convergences into each other" (Lind, 2005, p. 16).

The management literature that has dealt with analyzing the phenomenon of convergence, although having examined its impact on the redefinition of sectoral boundaries and corporate strategies, does not seem to have sufficiently deepened the general theme of the rapport between industrial convergence, innovation processes and selective mechanisms that work to define the evolution of the industries involved in these processes. Indeed, it is possible to state that, despite the fact that the overall industry convergence is increasing over time, the understanding of this phenomenon is still limited (Kim et al., 2015), also because with time technology convergence is evolving into a more complex and heterogeneous form (Jeong, Kim, \& Choi, 2015). For this reason, further exploratory and explanatory research is useful in understanding the consequences of convergence as a form of innovation and its impact on the evolution of convergent sectors (Hacklin et al., 2009).

Hacklin (2008, p. 11), one of the first scholars to have adopted, in the study of the convergence processes, an evolutionary perspective based on the analysis of the industrial technological changes over time, observed in this regard that industrial and technological convergence have been studied during the growth stage, or during phases of maturity, "but an integrated, comprehensive view of the convergence process, which could be used for understanding and managing through similar innovation trajectories in the future, can be regarded as still missing". He also noted that the study of industries where convergence development has reached a certain maturity (such as those of ICT macro-sector), might serve, in retrospect, as a basis for understanding the evolutionary dynamics in other sectors affected by the phenomenon of convergence.

This research work provides an original contribution in this direction. It was in fact analyzed the evolution over time of one of the sectors which in recent years has been most influenced by the digital convergence process, that of the mobile phones. This process brought the creation of a new related sector, that of smartphones, leading to radical changes in the structural and competitive characteristics of a series of sectors concerned, with different intensities and times, from the effects of this process. The overall objective of the work was therefore to analyze the processing phases of digital convergence that determined the birth and development of the smartphone sector and the dynamics of entry, exit and innovation over the industry life cycle. The use of a longitudinal analysis approach, based on the study of the historical sequence of events that led to the emergence and development of the smartphone industry over a period of more than 20 years, permits us to verify if some empirical regularities that characterize the evolution of firms and industries over time have characterized also the evolution of an industry born out of a sectoral convergence process. This is a relevant research question. As observed by Giachetti and Marchi (2010), research is in fact necessary to fill the gaps of classical industry life cycle model, especially when industry evolution is affected by disruptive events like those driven by technological convergence, as happened in the last years in the mobile phone industry. In this direction, this study offers several specific contributions. First, we examine the evolution of the smartphone industry, defined on the basis of sales data, to verify if it is in line with the evolutionary model that emerged from the product and industry life cycle studies. Secondly, we analyse the entry and exit processes over the industry life cycle of the smartphone industry and verify if the technological discontinuities that created the conditions for the development of this new converging industry have favored the entry, the survival and the competitive positioning of new entrants, compared to the incumbent firms, coming from the native converging sectors. Third, we analyze the evolution of product innovation over time in the smartphone industry to verify if it is consistent with the standard 
technological change identified by technology management and industry life cycle studies.

The article is organized as follows. In the next two sections a literature review concerning the industry life cycle evolution model and the phenomenon of sectoral convergence is carried out. Then, section 4 and 5 specify respectively the aims of the study and the research methodology. Section 6 describes the main phases of the convergence process underlying the birth and the development of the smartphone industry and the results of an empirical analysis aimed at examining the processes of entry, exit and innovation over the industry life cycle. Section 7 presents conclusions, limits, and future research directions.

\section{Entry, Exit and Innovation over the Industry Life Cycle}

The concept of Industry Life Cycle (ILC) has been developed in the academic literature to describe the evolutionary trajectories that normally characterize the industries from birth to maturity. The first seminar contribution on the topic was that offered by Vernon (1966) who, in studying the changes in international trade during the phases of the product life cycle, identified some patterns that characterize the evolution of industrial sectors. Over time, there have been numerous studies that have examined the evolutionary aspects of industrial structures. In line with the indications of Agarwal, Sarkar and Echambadi (2002), it is possible to include these contributions in three parallel research streams, those of organizational ecology, evolutionary economics, and technology management.

It is particularly in the study of evolutionary economists that the ILC concept has been more deeply understood. It is emphasized in this respect the contributions provided by Klepper $(1996,1997)$ that bring order to the aspects that characterize the evolution of firms and industries over time, placing them in the context of a broad and coherent theoretical framework (Audretch \& Feldman, 1996).

Klepper (1996) identifies a wide range of temporal and cross-sectional regularities that concern industry evolution and company behavior, building a formal model to explain such regularities. More specifically, there are six regularities identified, concerning how entry, exit, market structure, and technological change vary from the birth of industries through maturity. The analysis model proposed by Klepper is explicitly linked to the evolutionary patterns that characterize the industrial sectors during the product life cycle described in the works of Abernathy (1978) and Abernathy and Utterback (1978).

With regard to the empirical regularities pertaining to entry and exit during the ILC, Klepper observes in particular that "at the beginning of the industry, the number of entrants may rise over time or it may attain a peak at the start of the industry and then decline over time, but in both cases the number of entrants eventually becomes small" (Klepper, 1996, p. 564).

As regards, instead, to the empirical regularities that pertain to technological change, Klepper (1996, p. 565) affirms that, expecially for industries with rich opportunities for both product and process R\&D, "the diversity of competing versions of the product and the number of major product innovations tend to reach a peak during the growth in the number of producers and then fall over time".

These regularities have been identified considering the results of empirical studies that have examined the main recursive phenomena in the evolution of the structural and innovative characteristics of industrial sectors (Gort \& Klepper, 1982; Klepper \& Graddy, 1990; Utterback \& Suarez, 1993; Jovanovic \& MacDonald, 1994; Klepper \& Simons, 1996). They have also tended to be confirmed by most of the subsequent research on the subject (Agarwal, 1998; Agarwal et al., 2002; Dinlersoz \& MacDonald, 2009; Bos et al., 2013; Brenner \& Dorner, 2017).

In explaining the factors behind these empirical regularities, Klepper integrates the theories of the evolutionary economy with the assumptions underlying the study of technology management. He in fact examines the role of firms' innovative capabilities in influencing R\&D spending, innovation, and the market structure (Klepper, 1996). Entry into a sector is therefore interpreted as a vehicle to exploit the market opportunities opened up by market evolution and technological change in the industry. The determinants and causes of the entry process of new companies, therefore, to be fully understood, need to be analyzed with reference to the technological environment of the individual industries (Garavaglia, 2004). On this aspect Audrecht $(1995 ; 1997)$ and Anderson and Tushman $(1986,1990)$ propose evolutionary models of the industries that allow us to understand which typology of firms (incumbent or new entrant) are more able to enter or are more likely to exit a market. Audrecht (1996) starting from the consideration that knowledge conditions vary from industry to industry, observes that if, at the sectoral level, innovation processes tend to develop on the basis of routine activities - mainly leading to incremental innovations - they could be developed very effectively within the context of incumbent hierarchical bureaucracies; if, on the other hand, the innovation processes tend to come from knowledge that is not of a 
routine nature - often giving rise to radical innovations - they are often rejected by the hierarchical bureaucracies of incumbent corporations, favoring the entry in the industry of new competitors. The scholar, therefore, is connected to the theoretical approach of the 'technological regimes' proposed by Nelson and Winter (1982) which, in examining how the dynamics of innovation in a sector can change over time and also be different from industry to industry, analyze the economic and competitive transformations at the sectoral level influenced by these dynamics. They identified two distinct regimes: the routinized regime is one in which the innovative activity is based on accumulated stock of non transferable market-based expertise, thus fostering the established firms in the sector; the entrepreneurial regime in which, instead, the innovation processes are more accelerated and radical, devaluing the consolidated knowledge possessed by the incumbent companies and favoring the new entrants.

In addition to this, the 'cyclical model of technological change' proposed by Anderson and Tushman (1990) is connected to the approach of technological regimes. These scholars, on the basis of a longitudinal study of the evolution of some industries, indicate that the type of technological discontinuity that characterizes a specific industry affects the processes of entry and exit. Specifically, referring to the concept of entrepreneurial regime, they report that "a competence-destroying discontinuity renders obsolete the expertise required to master the technology that it replace", facilitating the entry of new companies in the sector and supporting their competitive capacity. On the other hand, in line with the concept of routinized regime, these scholars point out that "a competence-enhancing discontinuity builds on know-how embodied in technology that it replaces", giving particular value to the resources and skills of incumbent companies (Anderson \& Tushman, 1990, p. 608).

\section{Industry Convergence and Market Evolution}

The observations carried out approach the issues related to the ILC to those addressed by the scholars of industry convergence. This phenomenon has become the focus of attention of many researchers who have analyzed the changes that, since the end of the $80 \mathrm{~s}$, have made the boundaries of many industries 'blurred' and changeable, giving place to converging industries characterized in some cases by well-defined boundaries, in others by mobile confines, in continuous change and difficult to be defined (Weaver, 2007). The convergence process is therefore a phenomenon which, by its nature, has brought about relevant and continuous changes in the structure of various industries, leading to the emergence of a 'hybrid competition' (Ancarani \& Costabile, 2009) taking place between companies from different sectors.

In the field of economic-managerial literature, it is from the mid-90s that most of the research that has deepened, in a broad sense, the analysis of the industry convergence phenomenon. Most of them have primarily gone deeply into the analysis of drivers that have brought about this process and the examination of different types of convergence (Katz, 1996; Yoffie, 1997; Greenstein \& Khanna, 1997; Collis, Bane, \& Bradley, 1997; Pennings \& Puranam, 2001; Wirtz, 2001; Stieglitz, 2003; Lind, 2005). More have focused their attention on studying the impact of the sectoral convergence process on the business strategies and skills needed to face the changes imposed by this process (Gambardella \& Torrisi, 1998; Kaluza, Blecker, \& Bischof, 1999; Lei, 2000; Bores, Saurina, \& Torres, 2003; Lee, Lee, \& Cho, 2009; Lee, Olson, \& Trimi, 2010). Still, others have examined the international impact of convergence on regulatory policy, especially in the telecommunications industry (On \& Aoki, 1998; Clements, 1998; Bijl \& Peitz, 2008).

It is important to highlight that most of these studies have focused particular attention on the changes generated by digitalization and innovations in information and communications technologies. It is in fact in the industries within the ICT macro-sector that these processes have placed companies in the face of radical changes in terms of technologies, consumers and needs, causing profound changes on industry evolution. The results of these studies have provided interesting research insights that have allowed us to better approach the examination of the dynamics of entry, exit and innovation over time in converging sectors, thus integrating the explanations proposed by the evolutionary and technological perspectives.

Some studies have examined the relationship between the processes of convergence and the evolution of sectors, with particular reference to changes in the balance of power between the incumbent and new entrants induced by these processes. Stieglitz (2003) in this regard notes that the radical changes imposed by some types of convergence processes (convergence in technological substitutes and convergence in product complements) are difficult to deal with for incumbent companies, usually more efficient and effective in the development of incremental innovations, based on the exploitation of knowledge already possessed. Yoffie (1997) points out, however, that the small start-up companies, following unconventional radical ways to create innovative products, are often more competitive in new industries born out of digital convergence than the established players.

As observed (Hamel, 1991; Ancarani \& Shankar, 2003; Baer, 2004), incumbent firms have often sought to 
respond to technological changes at the base of the convergence processes by trying to modify or supplement its core competencies in line with the new demands of the market. This has often happened through inter-firm collaborations aimed at accessing complementary knowledge not yet possessed. However, these responses have not always proved adequate in coping with the profound transformations caused by technological discontinuities connected to the digital convergence (Collis et al., 1997; Stieglitz, 2003; Christensen, 1997).

Lind (2005, p. 14), precisely starting from the consideration that "convergence takes place at the intersection of change between technologies, industries, products, and markets", notes that the convergence is an elusive and multi-faceted concept, whose effects are difficult to interpret with existing frameworks. He, therefore, in examining structural and competitive changes of the sectors affected by the processes of convergence, intends to enter the convergence phenomena in the scope of an integrated theoretical framework that uses explicitly the results of the research conducted in the field of technological changes and evolutionary economics. Similarly, Stieglitz (2003), to examine the convergence process on the basis of the evolution of the handheld computer device market during the 90 's, uses evolutionary economics and industry life cycle theories as a key to understand the phenomena investigated. In line with this approach, Hacklin (2008, pp. 4-5) observes that the managerial literature relating to the convergence processes seem focalized a lot on the symptoms rather than on an investigation of the nature of the mechanisms underlying these processes and that, as a result, it does not seem to have addressed in an integrated and systematic way the association between convergence and innovation management. Thus, the scholar proposes that "convergence should be approached from a more innovative theory-oriented perspective, in order to bring about more comprehensive frameworks". To analyze the disrupting and break-through effects of digital convergence on the industrial evolution and to identify the capabilities necessary for value creation beyond blurring industry boundaries, so it is necessary to investigate the coevolutionary development of firms, technologies and industries over time (Hacklin et al., 2009).

\section{Aims of the Study}

The general aim of this work is to analyze the digital convergence process that led to the development of the smartphone sector and the dynamics of entry, exit and innovation over the Industry Life Cycle (ILC). In particular, examining the historical sequence of events that led to the emergence and development of the smartphone industry from the middle the ' 90 s to 2018 , we have verified if several empirical regularities that characterize the evolution of firms and industries over time - which have emerged by research of evolutionary economics and technology management studies - have distinguished also the evolution of this industry born out of a sectoral convergence process.

This research topic is relevant, considering that there are still few studies in the economic-managerial field that have investigated the impact of the convergence process on the evolution of the smartphone market from the micro point of view of companies and from the meso and the macro one, that are connected to the industrial sectors involved in this process (Dopfer, Foster, \& Potts, 2004). Therefore, there is a lack of knowledge about the effects of digital convergence on the innovation processes and selective mechanisms at the base of the evolution of the smartphone sector. This is also because the convergence process at the basis of the development of this industry is still in progress.

To understand in depth how the changes brought about by digital convergence has influenced the evolution of the mobile phone sector and of the others converging industries, evolutionary and technology management theories are used in a combined manner, and also the findings of managerial studies that have analyzed the phenomenon of sectoral convergence and its impact on industry evolution and business growth strategies. In coherence with this approach it is opportune to specify as an introduction that the term 'convergence' used in this work refers to a market and industry redefinition. In line with Lind $(2005$, p. 2), convergence is therefore understood as "a confluence and merging of hitherto separated markets, removing entry barriers across the market and industry boundaries".

The general objective of the work is connected to a series of specific research questions.

First of all, in accordance with the indications of the product and industry life cycle studies that have shown how the various stages of this cycle are defined and distinguished by their differing patterns of sales growth, the evolution over time of the smartphone industry is described on the basis of sales data in the world of such devices. This is to verify:

1.1) if the sales curve of the smartphone industry followed the 'S-shaped pattern', in line with the evolutionary model that emerged from the product and industry life cycle studies;

1.2) if the evolution over time of sales of the smartphone industry is connected to the trend of the market sales of 
the converging sectors from which it seems to have originated.

A second aspect analyzed concerns, instead, the study of firms' entry and exit processes over time in the smartphone sector. As noted, most sectors follow an evolution of industrial demography that passes through later stages. From the empirical studies there are mainly two plausible temporal patterns of entry: in the first the number of firm entries reaches the highest level at the beginning of the industrial evolution and therefore decreases, while based on the second, the number of firm entries increases in time and therefore decreases. In both cases, as noted (Klepper, 1996, p. 564), "the number of firms rises initially and then declines over time".

Consistently arising from research on the topic, especially in the field of technology management, it has also emerged that if the innovation processes are based on the development of existing knowledge and skills, the sector is mainly characterized by a technological change that enhances skills and competencies already held by established firms. Instead, in the case that the industry is characterized by a 'competence-destroying' discontinuity, incumbent companies often have difficulty in adapting their knowledge base to respond to the new technological opportunities offered by this change. If we adapt this reasoning to the context of the sectors affected by a sectoral convergence process, it is possible to highlight that the type of technological change that guides this process, and therefore the typology of digital convergence, can produce different effects in the power relationships between incumbent companies, coming from the converging sectors, and new entrants. As noted by Stieglitz (2003), in fact, when the convergence process favors the development of new technologies for which the level of cumulativeness of knowledge is low, it gives rise to a 'competence-destroying' discontinuity. Thus, opening the possibility of entry into the sector by a large number of new firms that can rapidly acquire relevant positions in the market. When, however, the level of cumulativeness of technological and marketing knowledge associated with the convergence process is high, it gives rise to a 'competence-enhancing' discontinuity. This hinders the entry of new firms and consolidates industry leadership in the larger organizations coming from converging industries, which can build on their existing competencies and products, and use these as the starting point for the development of hybrid products required by the new market born under the convergence process.

We then proceed to verify, in relation to the convergent sector of smartphones:

2.1) if during the different phases of ILC the number of firms grew initially and then reached a peak, after which it started to decline;

2.2) if the technological changes at the base of the digital convergence process have favored the entry and survival over time of established firms, coming from sectors from which the smartphone industry seems to have originated (Personal digital assistant and Features phone industries), or whether they have instead supported the entry and survival of new firms, previously not active in the native converging industries.

A third aspect analyzed is relative, finally, to the study of innovation processes over the ILC of the smartphone industry. As has been observed, the studies on the subject have shown that product innovations are normally very frequent in the initial phases of development of the sector, to then decline over time to the advantage of an increase in process innovations.

3 ) if product innovation has grown in the early stages of the ILC, have reached a peak during the growth phase, and then folded over time.

\section{Research Methodology}

From a methodological point of view, a longitudinal analysis approach was carried out to study in depth the ILC of the smartphone sector and the factors that have influenced its evolution over time. A historical method of analysis was therefore used, consistent with the study of phenomena that can be understood only by examining the temporal sequence and the type of events underlying the structural and competitive transformations of a sector (Nelson \& Winter, 1982; Gort \& Klepper, 1992; Anderson \& Tushman, 1990). The main events that led to the emergence and development of the smartphone industry were therefore analyzed, over a period of more than 20 years, from the middle of the ' 90 s to 2018.

To answer to the first research questions, the evolution over time of the smartphone industry, defined on the basis of sales data, was then drawn up and also that of the two converging markets - that of the Personal digital assistant and of the Mobile (feature) phone - from which the smartphone industry seems to have originated. For this purpose, the market data provided by the leading research institutes specializing in the sector - Gartner Group and International Digital Corporation (IDC) - was processed.

To describe the evolution over time of the number and type of companies operating in the smartphone industry at a global level, as well as to analyze product innovations launched on the market by these companies, consistent with the other research questions of this study, a series of secondary sources were used: 
- First of all, the data relating to smartphone producers active in the period from 2002-2018, supplied by the database managed by 'GSM Arena', have been appropriately processed. 'GSM Arena' is an independent organization that continuously collects information on production in the world of mobile phone devices, and conducts accurate analysis of the technological features of these devices. The reliability of this database is confirmed by previous research in the economic-managerial field (Cecere, Corrocher, \& Battaglia, 2015; Giachetti \& Dagnino, 2014; Giachetti \& Marchi, 2010; Koski \& Kretschmer, 2007) who have used this data to analyze the innovation and competition processes in the mobile phone industry, affirming it as a reference source for studies on the subject. The companies included in the 'GSM Arena' database operate at the international level. Small domestic operators active only in a national context are therefore excluded. Within the database provided by 'GSM Arena', only the companies that, more than occasionally (Note 1), produced and launched on the market smartphones - that is cell phone equipped with a mobile operating system - were selected. They were therefore excluded from the dataset analyzed producers of just feature phones (traditional cell phones with basic functionality and without a mobile operating system), as well as the producers of only tablets and smartwatches;

- For the purpose of clarification of some information provided by the 'GSM Arena' database, that have used some supplementary data provided by 'Phone DB' (formerly PDAdb.net), another specialized operator who, since 1989, designed and maintains a detailed mobile device database;

- The smartphone manufacturers' websites, as well as annual reports and press releases when available, were used to obtain information to make a distinction of the companies between 'incumbent' and 'new entrants', based on their sector of origin. As detailed in paragraph 6.3, this distinction represented the prerequisite to examine if the technological changes at the base of the digital convergence process have favored the entry and survival of established firms, coming from sectors from which the smartphone industry originated, or whether they have instead supported the entry and the position of new firms, not coming from the native converging sectors;

- Finally, books, newspapers, press releases and business publications concerning the history and the evolution of mobile and smartphone industry were used.

The resulting dataset elaborated utilising all these sources contains 4,891 smartphone models launched on the market from 2002 to 2018 by 83 manufacturers, classified on the base of their sector of origin.

The specific modality of data processing and the main indicators used for analysis are described in the course of this work.

\section{Results and Discussion}

\subsection{The Convergence Process and the Birth and Development of the Smartphone Industry}

The smartphone industry was born, in an embryonic form, in the late 1990s, when there was a digital convergence process that favored the creation of some prototypes of hybrid digital devices that combined the functionality of handheld computers - also called Personal Digital Assistant's (PDA's) - with mobile phones. The industries which produced these two devices responded to different customer needs. The PDA industry, born in the 1980s, saw involved companies such as Hewlett-Packard, Sharp, Casio, and Psion that sold electronic devices with features such as those of clock, calendar, calculator and access to a simplified database and to software for processing (Stieglitz, 2003). The mobile phone industry, which was born in the late 1970s, instead produced mobile devices that were focused on voice function and were dominated by companies coming from the telecommunication sector, such as Motorola, Ericsson and Nokia (Giachetti \& Marchi, 2010).

A series of technological innovations developed between the end of the last century and the first years of the new millennium have become the main driver of a digital convergence process which, over time, seems to have determined a complete overlay between these two industries. This refers to the advances in the field of miniaturization of hardware components, the process of digitalization of the contents, the evolution of telecommunication network technologies (GSM, GRPS, UTMS, i-mode) and to the introduction of wireless technologies which have permitted the connecting of electronic devices to a local communication network (Wi-Fi technology) or to a personal communication network (Bluetooth technology). These innovations have been exploited by the companies of the two sectors to empower the functionality of the respective mobile devices.

One of the first cell phone companies to create a hybrid device was Nokia, which in 1996 launched the Communicator model, which was the first phone on the market to have a display in landscape orientation and keyboard similar to that of handheld computers (Fling, 2009). This cell phone could send and receive faxes and SMS's and could connect to the Internet, as well as having the clock, calculator and calendar functions. The 
Communicator model was not a commercial success, but started a series of initiatives by other telephony companies that introduced innovative forms of hybrid devices (Stieglitz, 2003).

A further decisive step towards the creation of smartphones took place in 1998, when the top three operators of the mobile phone market (Nokia, Motorola and Ericsson), seeing the opportunities arising from the convergence process, established a joint venture called Symbian with Psion, a leading company in the PDA industry. The aim of this joint venture was to create a network of specialized skills for the creation of an innovative operating system for the latest generation mobile phones (Ancarani \& Shankar, 2003). The Symbian project was the indicator of a major change in the field of mobile telephone devices, as the idea was affirmed that, with the development of ICT technologies, alongside the hardware component, the cell phone software assumed a key role, transforming it into a different device, with functions that over time would come closer to those of a pocket computer than to those of a cell phone. Starting from the experience of the Symbian operating system, all the companies in the sector have paid greater attention to the role of the software platform, giving rise to a market for mobile operating systems that over time would acquire its own specificity, contributing decisively to the affirmation of the smartphone industry (Kenney \& Pon, 2011).

Even the operators of the PDA industry tried to add new features to their devices that could take advantage of the technological innovations, although most of them initially tended to focus on growth strategies in the original business (Stieglitz, 2003). An important contribution to the development of smartphones, however, was provided in 1999 by the market launch by Research in Motion (RIM) - a Canadian company specializing in wireless communication technologies - of the BlackBerry, a PDA that, although it did not have the voice function, allowed businessmen to access e-mail remotely. This device was the predecessor of the first smartphone launched on the market by RIM in 2002, the BlackBerry 5810, which allowed, in addition to telephone calls, to send and receive messages, access e-mail and surf the Internet (Campbell-Kelly et al., 2015). The innovative characteristics of this smartphone made RIM become one of the main protagonists of the first period in the development of the smartphone market.

The overlap between these sectors led to the development of a first form of 'intelligent cell phones', which were also rapidly enriched with new features, thanks to innovations in the fields of digital audio and video devices. Most manufacturers of mobile phones and PDA's launched on the market some devices that included digital cameras and camcorders, and digital media players for the new audio format MP3 (Hill, 2013). The convergence process was then accelerated by consumer demands, that expressed a need for simplification and a want to use the same apparatus to perform the functions of a variety of mobile digital devices (phone, camera, audio player, video equipment, etc.) (Kim, Lee, \& Koh, 2005).

However it is from 2007, the year in which Apple, with the launch of the iPhone on the market, played the role of 'forerunner' towards a new way of using the smartphone (West \& Mace, 2010), causing the final transition of the industry from a phase of introduction to a sustained growth. Specifically, Apple created for the iPhone an exclusive proprietary operating system, the 'iOS', adapting the advanced 'Mac OS' software used for their personal computers. The adaptation took place by simplifying the use of the various functions of the device, especially those connected to the use of the Internet. One aspect that differentiated the operating system of the iPhone from that of the competitors was the adoption of a graphic interface based on the use of easily selected 'icons' which, combined with a multitouch screen with a high graphic resolution, allowed one to interact with the smartphone quickly (a solution then established as a standard). A year after the launch of the iPhone, Apple also introduced a further relevant innovation. The company launched a section of the iTunes virtual store, called App Store, from which were released a series of thematic multimedia software applications with the aim of providing value-added services to the customer of the iPhone (West \& Mace, 2010; Kenney \& Pon, 2011). By that time the other players in the smartphone market had created 'Mobile Application Stores', being forced by the risk of losing market position to Apple.

The introduction of software applications for the smartphone also had an impact on the development of mobile operating systems. In 2007 the market leader in this business was the Symbian software, which has been discussed previously, used under license by 63.5 percent of smartphones on the market (Gartner Group, 2009). In 2008 Google, a company operating in the Internet based services sector, launched the Android operating software on the market. Its business model differed from that of the other software sector operators. The company, not having the in-house skills for this type of product, had acquired the Android software company in 2007, creating a consortium for the development of the program (Querbes-Revier, 2011). They therefore decided to make this operating system license-free and selectively open. The Android operating system has therefore become attractive to several smartphone manufacturers, especially those of East Asia, who have been able to enter the sector also thanks to access to this open source software even though they do not have the skills to 
provide their devices with advanced software programmes (Kenney \& Pon, 2011; Campbell-Kelly et al., 2015; Fautrero \& Gueguen, 2013). The market has rewarded Google's mobile operating system. There has been in fact affirmed over the time stated a duopoly in the smartphone operating system market that consists of Google, which, with a market share of about 85 percent, provided in 2018 the open system Android in almost all the smartphone manufacturers, who were able to outsource the management of this software component; and Apple, which covered around 15 percent of the market with the proprietary closed iOS system, that equips its own devices exclusively (Statista, 2019).

\subsection{The Results of the Empirical Research: The Sales Curve of the Smartphone Industry}

From the described factors and the major steps that led to the birth of the smartphone industry, it is possible to address the first specific objective of the research, that is, to examine the evolution of the smartphone industry defined on the basis of sales data. That is in order to verify: 1.1) if the sales curve of the smartphone industry followed the 'S-shaped pattern', in line with the evolutionary model that emerged from the product and industry life cycle studies; 1.2) if the evolution over time of sales of the smartphone industry is connected to the trend of the market sales of the converging sectors from which it seems to have originated.

As specified in the description of the work methodology, the evolution of the sales of the smartphone industry, and of the main converging sectors - that of the Personal digital assistant and of the Mobile (feature) phone from which the smartphone industry seems to have originated, was defined by processing the sales data from 2002 to 2018, provided by the main specialized research institutes in the sector (Gartner Group and International Digital Corporation - IDC -).

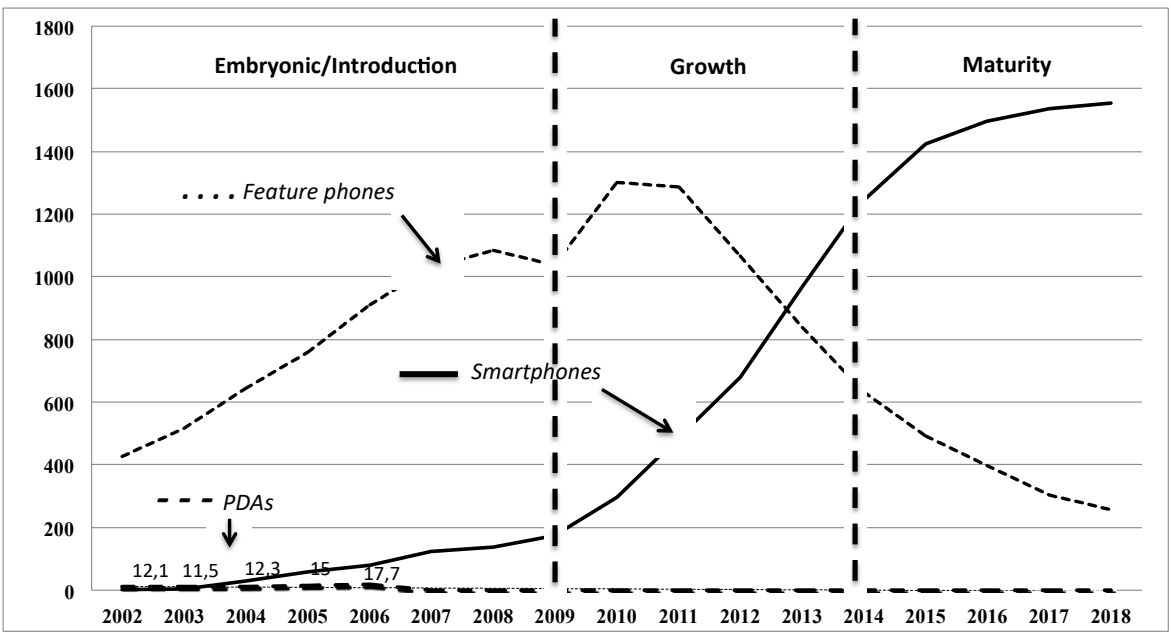

Figure 1. The sales curves of the smartphone industry and of native converging sectors (sales in the world of

'Smartphones', 'Feature phones' and 'Personal Digital Assistants') (millions of units) (Years 2002-2018)

Source: our processing of data from Gartner Group and International Digital Corporation (IDC).

The results of the analysis permits, first of all, to show that the evolution of market sales in the smartphone industry (expressed in terms of the number of units) seems to have followed the 'S-shaped pattern' highlighted in the literature. From the graph of Figure 1, in fact, it shows a trend of the sales curve of the smartphone industry that allows for identifying various developmental stages of the sector, defined by their differing patterns of sales growth: firstly, an embryonic/introduction stage, which lasted up to 2009, in which sales of smartphones were steadily and progressively increased; a second phase of accelerated growth - as demonstrated by the values relating to the slope of the ILC curve - on the basis of annual growth rates in sales that were particularly high (with values never reached before or after this phase). That is in correspondence of entry into the sector of technological and market innovations proposed - as described - by Apple (iPhone) and Google (Android). From 2015 , however, the sector seems to come to a first stage of maturity (Gartner Group, 2019a; 2019b). The rate of sales growth and then the slope of the ILC curve have in fact declined sharply, finally confirming a stability of sales in 2018 compared to 2017. It should, finally, be highlighted that the industry is still in a stage of evolution and that only the analysis of data relating to sales performance over the next few years will provide indications of future development phases. This is consistent with the historical approach of analysis adopted in this work and 
does not aim to predict the future entry of the sector in a phase of growth, stability or decline.

Continuing with the analysis of sales data, it emerges that the evolution of the sales curve of the smartphone industry was accompanied by a radical change in the evolution of the sales curves of the convergent sectors from which this sector originated. It is apparent that there has been a convergence/substitution process of traditional cell phones with basic functionality and without a mobile operating system - feature phones - and Personal Digital Assistants, with smartphones. As is evident in Figure 1, the market for 'feature phones' touched a peak of sales in 2010, which was followed - in correspondence with the accelerated growth phase of sales of smartphones - by a stage of decline, which in a just a few years brought sales of this type of mobile phone to more limited values (Note 2).

The growth phase of the smartphone market was also accompanied by the final decline of the PDA industry. At the beginning of 2000, this sector was still in an initial developmental phase. In fact, being the PDA a product which was mainly aimed at a business market, its sales - which reached in 2006 a peak maximum of almost 18 million units - did not evolve the sector towards a mass market. The full overlap of this sector with the smartphone sector has been indirectly confirmed by the research institutes that specialize in the survey of sales data. In fact, since 2007 PDA sales have been counted as part of the new smartphone industry. This is because most of these devices however included cellular connectivity, leading to a difficult distinction between PDAs and advanced mobile phones with mobile operating systems (Gartner Group, 2007).

\subsection{The Results of the Empirical Research: Entry and Exit over the Industry Life Cycle of the Smartphone Industry}

Having described the evolution of the smartphone industry on the basis of sales data, we analyze the dynamics of entry and exit of firms over time in the sector.

Coherently with the specific objectives of the research in mind, it was first tested if - consistent with one of the empirical regularities identified by the studies on the ILC - during the different phases of ILC of the converging smartphone industry the number of firms increased initially, then reached a peak, after which it started to decline. To do this - as analyzed in more detail in the description of the research methodology - the data provided by the 'GSM Arena' database which was processed to examine the number and type of companies active in the smartphone industry in the world in the period from 2002-2018. The result of the analysis is that companies that have operated, more than occasionally, in the smartphone industry during this period were a total of 83, of which just over half (46) are still active in 2018. In more detail, as graphically shown in Figure 2, a substantial trend of continuous growth of the number of entries in the early stages of the development of the sector has been verified. The number of entries was particularly high in the growth phase of sales in the sector, then began to decline over time into a first phase of maturity of sales. On the contrary, the number of exits from the industry remained fairly contained in the introduction and growth phases, and than augmented considerably with entry into the maturity phase of sales.

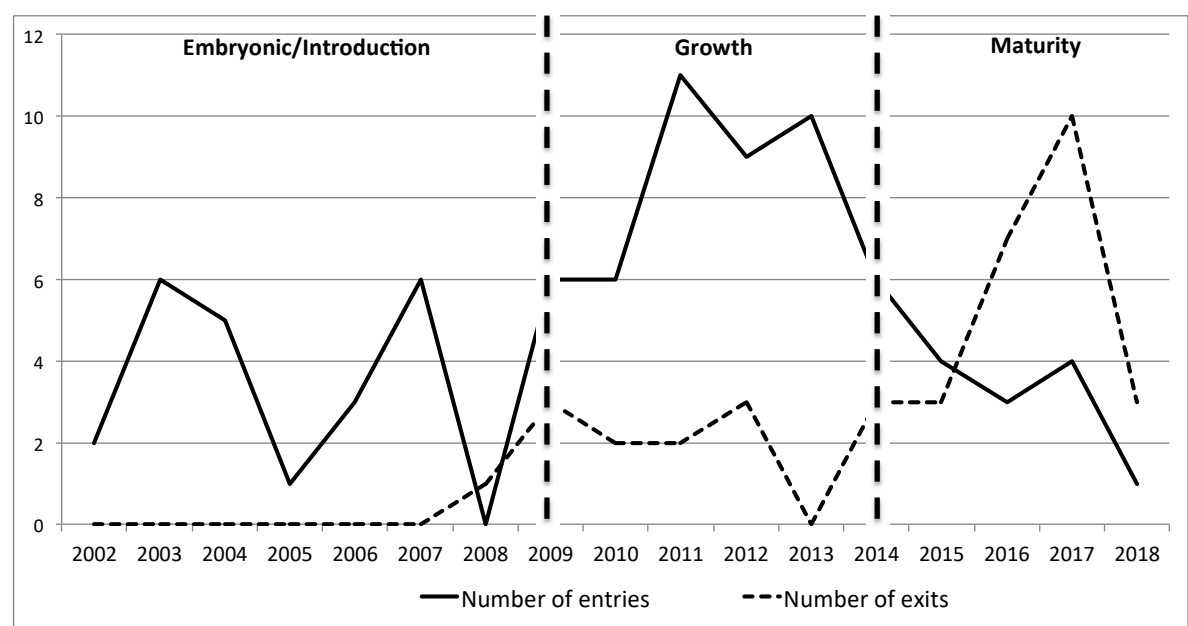

Figure 2. Entry and exit over the ILC of the smartphone industry (number of firms) (Years 2002-2018)

Source: our processing of data from 'GSM arena' (www.gsmarena.com).

The result of these entry and exit dynamics over time on the industry's firm population is described in Figure 3. 
The total number of companies in the sector grew steadily in the first phase of introduction, and then rose faster in the growth phase of sales, at the end of which it reached a peak. This was followed - with the entry of the industry into a first phase of maturity of sales - by a slow but progressive decrease in firm population. The entry and exit dynamic of firms in the smartphone industry, therefore, seems rather in line with the temporal patterns proposed by the literature on ILC.

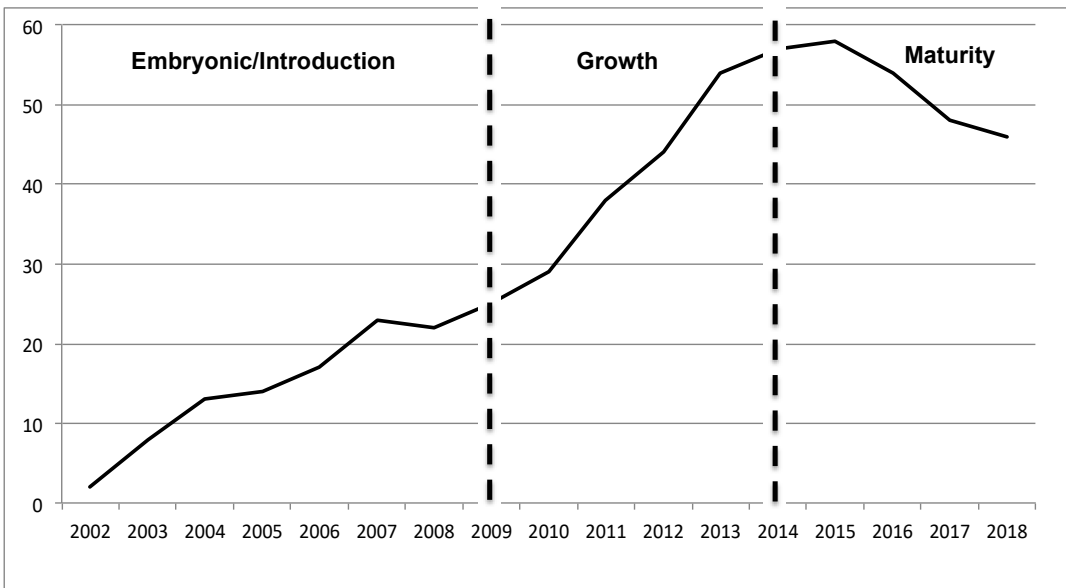

Figure 3. Firm population over the ILC of smartphone sector (number of companies) (Years 2002-2018)

Source: our processing of data from 'GSM arena' (www.gsmarena.com).

An in-depth analysis of the type of active companies over the ILC of the smartphone sector was then carried out.

As described, the smartphone sector originated from a process of digital convergence between the mobile (feature) phone and the PDA sectors. It was then examined if the technological changes at the base of the digital convergence process have favored the entry and survival over time of established firms, coming from sectors from which the smartphone industry originated, or whether they have instead supported the entry and the position of new firms, not coming from the native converging sectors.

The evolution in the number of smartphone manufacturers over the ILC was therefore examined, distinguishing between 'incumbent' and 'new entrants' firms. This distinction was then made based on the sector of origin of the companies.

The firms coming from the two sectors - that of the Mobile (feature) phone and of the PDA - from the overlap of which the smartphone industry originated, have been classified as 'incumbents'. These firms used existing products as the starting point for the development of a hybrid product such as the smartphone. They are, in fact, the ones who marketed exclusively the first forms of smartphones in the first years of the 2000s and that, in that period, dominated the general sales of mobile phones and of handheld computers, in the area from which were accounted the residual sales of smartphones.

However, there has been classified as 'new entrants' those companies that have previously not been active in the native converging industries and who have made their entry into the market from 2005: 1) through a strategy of diversification, coming from uncorrelated sectors or from sectors that only in a second phase have entered into partial overlap with that of smartphones (especially those of the software and hardware for computers); 2) through the creation of start-up firms ('greenfield entry', Mueller, 1991).

In order to carry out this classification, an in-depth investigation - based on the derived sources illustrated in the paragraph in which the research methodology has been described - was carried out which allowed us to determine the original sector to which all the 83 companies active in the period under analysis belonged. The results are synthetically represented in Figure 4. 


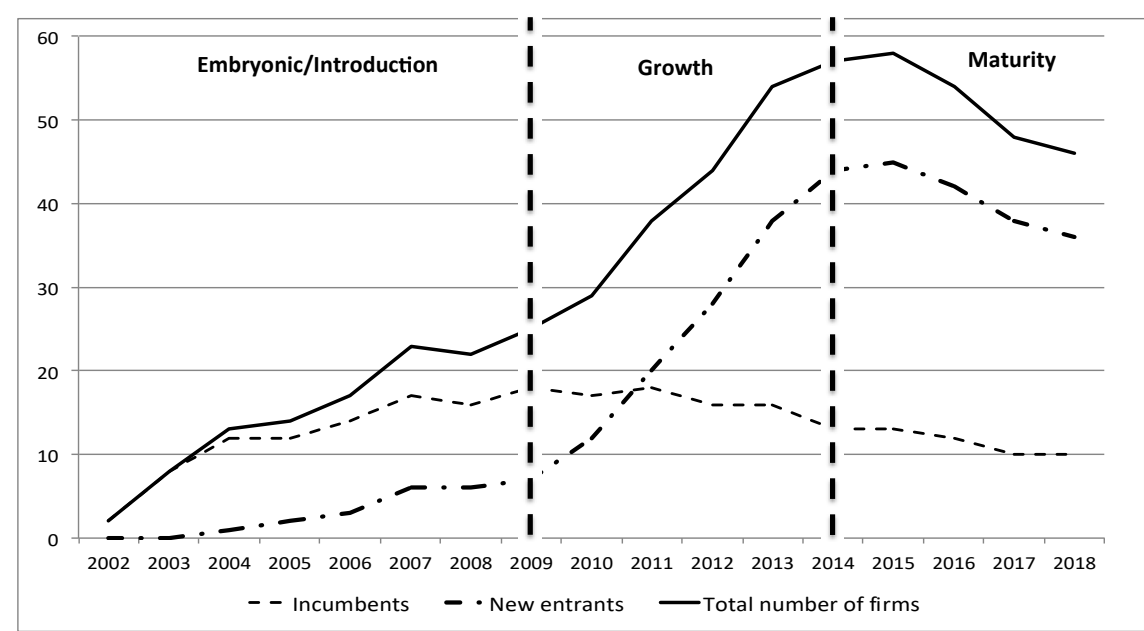

Figure 4. Firm population over the ILC of the smartphone sector: incumbent vs. new entrant firms (number of companies) (Years 2002-2018)

Source: our processing.

Figure 4 shows that of the 46 companies active in the smartphone industry in 2018, almost 80 percent of these (36) consist of new entrants, where only 10 are companies that came from the sectors of mobile phones or PDAs. From an in depth examination, it can be detected that the number of the firms that we have defined as 'incumbents' has first slightly grown to a maximum of 18 in 2009, to then decline to 10 in 2018 . This trend is the result of the entry and exit process that led to a rate of average survival of companies equal to 38 percent. This rate was calculated as the ratio between the number of incumbent firms still active at the end of the analyzed period - year 2018 - equal to 10, and the total number of incumbent companies operating in the market from 2002-2018, which amounted to 26. In this regard, it is sufficing to point out that the two incumbent firms Nokia (coming from the mobile phone industry) and RIM/Blackberry (coming from the PDA industry) - who were leading the smartphone industry in 2007 with a market share respectively of about 50 and 10 percent (Gartner Group, 2009), exited the market in 2013 and 2017.

If, on the other hand, the data relating to the new entrants is analyzed, it should be noted that their number has rapidly increased, especially in the growth phase of sales of the sector. These companies seem to have demonstrated an even greater ability to adapt to the evolution of the sector, because for them the average survival rate is about 63 percent, which is much higher than that of incumbent companies. This rate was always calculated as the ratio between the number of the 36 new entrants active in 2018 and the total number of the 57 new entrants' firms operating in the market from 2002-2018. A further demonstration of a greater capacity of these firms to adapt to the industry evolution in respect to the established firms, the market shares in 2018, while still signaling the leadership of an incumbent company (Samsung, coming from the mobile phone sector, which controls about 19 percent of the total sales in terms of units), highlight the pre-eminent position in the market of new entrants, which cumulatively control most of the market sales, expressed in terms of the number of devices sold. In particular, it emerges the increasingly relevant role covered in recent years by several firms from East Asia (such as Huawei, Xiaomi and OPPO), which are rapidly and steadily acquiring market shares over time by virtue of very high sales growth rates (Gartner group, 2019a).

\subsection{The Results of Empirical Research: Product Innovation over the Industry Life Cycle of the Smartphone Industry}

A final aspect analyzed is related to the study of the innovation processes during the ILC of the smartphone sector. In line with the specific objectives of the work it has been verified if - consistent with one of the empirical regularities of ILC identified in the literature - in the converging smartphone industry product innovation grew in the early stages of development, than reached its peak during the growth stage, and subsequently folded over time. It is opportune to specify in an introduction that product innovation in a sector can be measured in numerous ways. In this work the level of product innovation was measured considering the number of new versions of the product launched on the market by manufacturers of smartphones over the ILC. The data provided by the 'GSM Arena' database relating to the new versions of smartphones introduced in the 2002-2018 period were therefore processed. The examination of the data showed that overall the companies 
active during the period analyzed have put on the market 4,891 different versions of smartphones. An average annual product innovation rate was then calculated by comparing, for the entire period examined, the number of new product versions launched each year by active companies in the sector with the number of companies active in that year. The results of these calculations are presented in Figure 5.

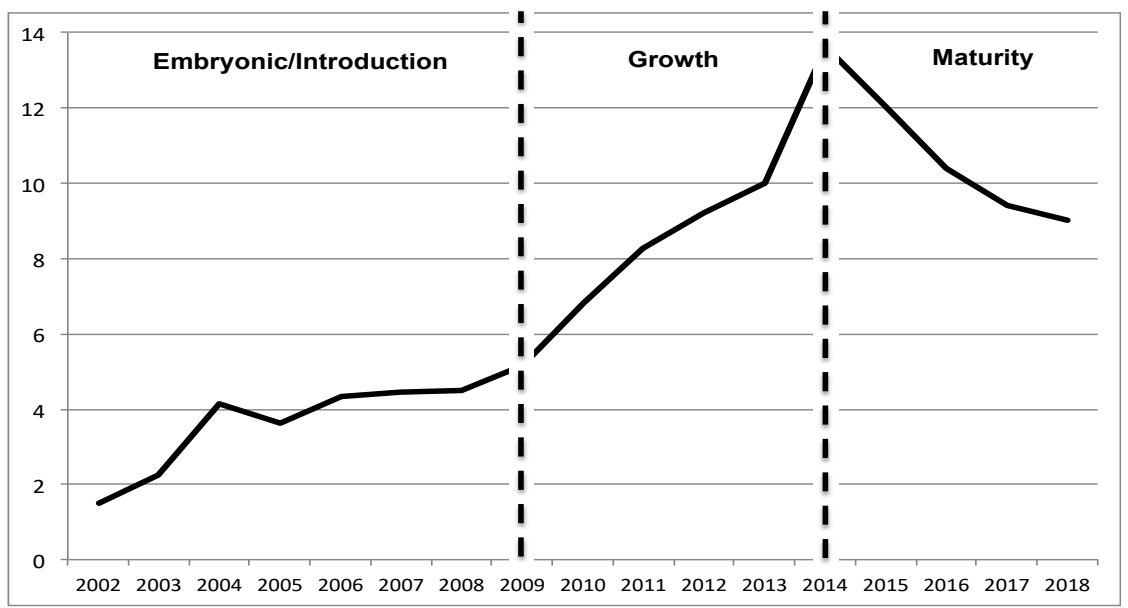

Figure 5. Innovation over the ILC of the smartphone sector: the average annual rate of product innovation

(new versions of smartphones) years 2002-2018

Source: our processing of data from 'GSM arena'. (www.gsmarena.com).

From the figure it emerges that the average annual rate of product innovation has steadily grown during the early stages of development of the ILC, in particular by accelerating and reaching a peak in the growth phase. In 2014, in fact, each company active in the sector had on average launched almost 14 new smartphone models on the market. With the start of the maturity phase of sales, however, the average annual rate of product innovation had begun a decreasing trend.

The results, therefore, appear in line with one of the ILC innovation patterns, when it is stated that "the diversity of competing versions of the product and the number of major product innovations tend to reach a peak during the growth in the number of producers and then fall over time" (Klepper, 1996, pp. 565).

\section{Conclusions, Limits, and Future Research Directions}

The analysis carried out allowed, in line with the aims of the work, to examine the digital convergence process that led to the development of the smartphone industry and the dynamics of entry, exit and innovation over the ILC of this converging sector. Although, as observed (Gort \& Klepper, 1992), the use of a historical method of analysis leaves many questions only partially resolved, some important results emerged from the analysis, as described below.

The first aspect examined concerned the evolution over time of the sales curve of the smartphone industry. The elaborations carried out allowed us to highlight that this curve followed the 'S-shaped pattern', in line with the evolutionary model that emerged from the product and industry life cycle studies. It was in fact identified in the following evolutionary phases defined by their differing patterns of sales growth: a first embryonic/introductory phase of the sector, which continued until 2009, when sales were steadily and progressively increased; a second phase of accelerated growth, based on particularly high annual sales growth rates, that were never reached before or after this phase; a third phase of maturity, that started in 2015, in which the sales growth rates gradually decreased to the point of stopping in 2018. The analysis also showed that the evolution of sales of the smartphone industry was accompanied by the concomitant entry into a phase of decline of sales of feature phones and PDAs. The study of the succession of events underlying the trend of these sales curves has allowed us to highlight in this regard that the first prototypes of 'intelligent cell phones' launched on the market were hybrid products that integrated the salient product characteristics of a PDA and a traditional mobile phone into one digital device. The birth of the industry therefore seems to have taken place following a progressive process of 'convergence in substitution' (Greenstein \& Khanna, 1997; Stieglitz, 2003) of feature phones and PDAs with new smartphones. 
A second aspect examined concerned the entry and exit processes over the ILC of the smartphone sector. In the first place, the analysis showed that the evolution over time of industrial demography is consistent with the temporal patterns detected by most empirical studies conducted on the theme of the evolution of new industries. Also in this industry born out of a sectoral convergence process it happened, in fact, that the number of entries grew steadily over time and then started to decline in the last few years, with the entry into a phase of maturity. The industry's firm population, therefore, grew slowly in the introduction phase, to then rise rapidly in the growth phase, during which it reached a peak. This is followed by a first slow but progressive decrease in the number of companies active in the sector throughout the maturity phase of sales, also due to an high increase in the number of exits.

The data relating to the entry and exit processes of the industry were then further elaborated to understand if the technological changes underlying the digital convergence process have opened up the possibility of entry for new firms, or if they have otherwise consolidated the positions of the established firms coming from the sectors from which the smartphone industry originated - that of the Mobile (feature) phone and of the PDA -. The analysis showed, in summary, that the technological opportunities that created the conditions for the creation of this new industry seem to have favored the entry, the survival and the competitive positioning of new entrants, compared to the incumbent firms coming from the native converging sectors.

These observations indirectly provide some interesting indications on the type of technological discontinuity underlying the development of the smartphone industry. As already highlighted, the studies on the ILC have shown that if the innovation processes are based on the development of existing knowledge and skills, the industry is mainly characterized by a technological change enhancing skills already possessed by incumbent companies, reducing generally the entry possibilities and the competitive strength of newcomers. If, on the other hand, innovation processes are based on new forms of knowledge, an industry tends to evolve by virtue of a competence-destroying technological change which, in devaluing the complementary resources normally possessed by incumbent companies, can favor greater entry into the industry by a large number of new operators. However, it is very difficult to be able to identify the type of technological change on the basis of sectoral changes while they are being realized. It has been observed in this regard (Anderson \& Thusman, 1990, p. 621) that to qualify the type of technological change it might be important to define an index "reflecting such factors as the amount of retraining required to master a new technology, the number of new skills a firm would have to acquire to exploit an innovation, or the degree to which models based on the old technology could be retrofitted with the new technology", but such data on technical competence were hardly available. Even the companies involved in digital convergence processes are not able to exactly reconstruct how they adopted new technology, and how their industries evolved. This is the reason why such scholars observe that "to know how to innovate affected previous know-how must rest on the judgment and informed argument of the historian". The historical method of analysis used in this work therefore allows us to provide some indications in this regard. In extreme synthesis, the results emerged from the examination of the type of companies (incumbent and new entrant) that have been active over the ILC of the smartphone sector and of their different competitive performances, joined with the outcome of the analysis of the convergence process at the basis of the development of the smartphone industry, allows us retrospectively to identity a process of 'convergence in substitution' that has determined a 'competence-destroying discontinuity'. This type of technological discontinuity - favoring the entry and competitive strength of new firms compared to established companies - has completely reconfigured the mobile phone and PDA industries from which the smartphone sector originated. This result is useful in addressing the research hypotheses of studies that will approach the comprehension of redefinition of the structure of the mobile phone industry and the competitive and innovative dynamics - actual and projected - of the smartphone sector.

Finally, another aspect analyzed concerned the evolution of innovation processes of the smartphone industry. Specifically, the processing of data relating to product innovation introduced over the ILC has highlighted that the average annual rate of product innovation grew in the early stages of development, then reached its peak during the growth phases of sales, and subsequently declined over time. The evolution of product innovation in this converging sector is therefore in line with the standard technological change over time identified by the literature on the evolution of new industries.

In conclusion, it should be pointed out that the method of analysis used permitted us to examine the research objectives one at a time, but not through a more complex, multivariate model. The results achieved may be considered however as an important point of departure to be able to structure a future research project aimed at identifying the possible relations that exist between the different phenomena investigated. The objective could be to measure, using statistical techniques, the evolution along the ILC of the smartphone sector, of the relations between market sales, the concentration index, exit and entry numbers, rates survival of companies, and product 
innovation rates. Taking also into consideration the differences that can be detected for these variables between new firms and incumbent firms.

\section{References}

Abernathy, W. J. (1978). The productivity dilemma. Baltimore: The Johns Hopkins University Press.

Abernathy, W. J., \& Utterback, J. M. (1978). Patterns of Industrial Innovation. Technology Review, 80(7), 40-47.

Agarwal, R, \& Gort M. (2002). Firm and product life cycles and firm survival. American Economic Review, 92(2), 184-190. https://doi.org/10.1257/000282802320189221

Agarwal, R. (1998). Evolutionary trends in industry variables. International Journal of Industrial Organization, 16, 511-525. https://doi.org/10.1016/S0167-7187(97)00004-0

Agarwal, R., Sarkar, M. B., \& Echambadi R. (2002). The conditioning effect of time on firm survival: an industry life cycle approach. Academy of Management Journal, 45(5), 971-994. https://doi.org/10.2307/3069325

Ancarani, F., \& Costabile, M. (2009). Concorrenza ibrida. Convergenza, tecnologie, esperienze di consumo. Milano: Pearson.

Ancarani, F., \& Shankar, V. (2003). Symbian: Customer Interactions through Collaboration and Competition in a Convergent Industry. Journal of Interactive Marketing, 17(1), 56-76. https://doi.org/10.1002/dir.10048

Anderson, P., \& Tushman M. (1990). Technological Discontinuities and Dominant Designs: A Cyclical Model of Technological Change. Administrative Science Quarterly, 35(4), 604-633. https://doi.org/10.2307/2393511

Audretsch, D. B. (1991). New Firm Survival and the Technological Regime. Review of Economics and Statistics, 73(3), 441-450. https://doi.org/10.2307/2109568

Audretsch, D. B. (1995). Innovation and Industry Evolution, Cambridge MA: The MIT Press.

Audretsch, D. B. (1997). Technical regimes, industrial demography and the evolution of industrial structures. Industrial and Corporate Change, 6(1), 49-82. https://doi.org/10.1093/icc/6.1.49

Audretsch, D. B., \& Feldman, M. P. (1996). R\&D spillovers and the geography of innovation and production. American Economic Review, 86(3), 630-640.

Baer, M. (2004). Kooperationen und Konvergenz. Frankfurt am Main: Lang.

Baum J. A. C. (1996). Organizational ecology. In S. R. Clegg, C. Hardy, \& W.R. Nord (Eds.), Handbook of organizational studies (pp. 77-114). London: Sage.

Bijl, D. P., \& Peitz, M. (2008). Innovation, convergence and the role of regulation in the Netherlands and beyond. Telecommunications Policy, 32, 744-754. https://doi.org/10.1016/j.telpol.2008.09.003

Bores, C., Saurina, C., \& Torres, R. (2003). Technological convergence: a strategic perspective. Technovation, 23(1), 1-13. https://doi.org/10.1016/S0166-4972(01)00094-3

Bos, J. W., Economidou, C., \& Sanders M. W. J. L. (2013). Innovation over the industry life-cycle: Evidence from EU manufacturing. Journal of Economic Behavior \& Organization, 86(1), 78-91. https://doi.org/10.1016/j.jebo.2012.12.025

Brenner, T., \& Dorner, M. (2017). Is there a life cycle in all industries? First evidence from industry size dynamics in West Germany, Applied Economics Letters, 24(5), 289-297. https://doi.org/10.1080/13504851.2016.1184369

Breschi, S., Malerba, F., \& Orsenigo, L. (2000). Technological regimes and Schumpeterian patterns of innovation. Economic Journal, 110, 338-410. https://doi.org/10.1111/1468-0297.00530

Campbell-Kelly, M., Garcia-Swartz, D., Lam, R., \& Yang, R. (2015). Economic and business perspectives on smartphones as multi-sided platforms. Telecommunications Policy, 39(8), 717-734. https://doi.org/10.1016/j.telpol.2014.11.001

Cecere, G., Corrocher, N., \& Battaglia, R. D. (2015). Innovation and competition in the smartphone industry: Is there a dominant design? Telecommunications Policy, 39(3-4), 162-175, 2015. https://doi.org/10.1016/j.telpol.2014.07.002

Clements, B. (1998). The impact of convergence on regulatory policy in Europe. Telecommunications Policy, 22(3), 197-205. https://doi.org/10.1016/S0308-5961(98)00007-X 
Collis, D., Bane, P., \& Bradley, S. (1997). Winners and loosers: industry structure in the converging world of telecommunications, computing and entertainment. In D. Yoffie, (Ed.), Competing in the Age of Digital Convergence (pp. 159- 200), Boston, MA: Harvard Business School Press.

Counterpoint Research. (2019). More than a Billion Feature Phones to be Sold over Next Three Years. Press Release, March $13 . \quad$ Retrieved from https://www.counterpointresearch.com/more-than-a-billion-feature-phones-to-be-sold-over-next-three-years

Christensen, C. M. (1997). The innovator's dilemma. Boston, MA: Harvard Business School Press.

Dinlersoz, E. M., \& MacDonald, G. (2009). The industry life-cycle of the size distribution of firms. Review of Economic Dynamics, 12(4), 648-667. https://doi.org/10.1016/j.red.2009.01.001

Dopfer, K., Foster, J., \& Potts, J. (2004). Micro-meso-macro. Journal of Evolutionary Economics, 14, $263-79$. https://doi.org/10.1007/s00191-004-0193-0

Fautrero, V., \& Gueguen, G. (2013). The dual dominance of the android business ecosystem. In S. B. Letaifa, A. Gratacap, \& T. Isckia (Eds), Understanding Business Ecosystems (pp. 211-238). Bruxelles: De Boeck.

Fling, B. (2009), Mobile Design and Development: Practical concepts and techniques for creating mobile sites and web apps. New York: O'Reilly Media.

Gambardella, A., \& Torrisi, S. (1998). Does technological convergence imply convergence in markets? Evidence from the electronics industry. Research Policy, 27, 445-463. https://doi.org/10.1016/S0048-7333(98)00062-6

Garavaglia, C. (2004). Analisi delle determinanti dell'entrata di nuove imprese nei settori industriali. Una rassegna. LIUC Papers, 144, Serie Economia e Impresa, 36. Retrieved from http://www.biblio.liuc.it/liucpap/pdf/144.pdf

Gartner Group. (2007). Gartner Says Worldwide PDA Shipments Top 17.7 Million in 2006. Retrieved from https://www.gartner.com/en/newsroom

Gartner Group. (2009). Gartner Says Worldwide Smartphone Sales Reached Its Lowest Growth Rate with 3.7 Per Cent Increase in Fourth Quarter of 200. Retrieved from https://www.gartner.com/en/newsroom

Gartner Group. (2019b). Gartner Says Global Smartphone Demand Was Weak in Third Quarter of 2019. Retrieved from https://www.gartner.com/en/newsroom

Giachetti, C., \& Dagnino, G. B. (2014). Detecting the relationship between competitive intensity and firm product line length: Evidence from the worldwide mobile phone industry. Strategic Management Journal, 35(9), 1398-1409. https://doi.org/10.1002/smj.2154

Giachetti, C., \& Marchi, G. (2010). Evolution of firms' product strategy over the life cycle of technology-based industries: a case study of the global mobile phone industry, 1980-2009. Business History, 52(7), 1123-1150. https://doi.org/10.1080/00076791.2010.523464

Gort, M., \& Klepper, S. (1982). Time Paths in the Diffusion of Product Innovations. Economic Journal, 92(367), 630-653. https://doi.org/10.2307/2232554

Greenstein, S., \& Khanna, T. (1997). What does industry convergence mean? In D. Yoffie (Ed.), Competing in the Age of Digital Convergence (pp. 201-226). Boston, MA: Harvard Business School Press.

Hacklin, F. (2008). Management of Convergence in Innovation. Heidelberg: Physica Verlag.

Hacklin, F., Marxt, C., \& Fahrni, F. (2009). Coevolutionary Cycles of Convergence: An Extrapolation from the ICT Industry. Technological Forecasting and Social Change, 76(6), 723-736. https://doi.org/10.1016/j.techfore.2009.03.003

Hamel, G. (1991). Competition for Competence and Inter-Partner Learning Within International Strategic Alliances. Strategic Management Journal, 12, 83-103. https://doi.org/10.1002/smj.4250120908

Hill, S. (2013). From J-Phone to Lumia 1020: A complete history of the camera phone. Digital trends. Retrieved from https://www.digitaltrends.com/mobile/camera-phone-history/

Jeong, S., Kim, J., \& Choi, J.Y. (2015). Technology convergence: What developmental stage are we in? Scientometrics, 104, 841-871. https://doi.org/10.1007/s11192-015-1606-6.

Jovanovic, B., \& MacDonald, G. (1994). The Life Cycle of a Competitive Industry. Journal of Political Economy, 102(2), 322-347. https://doi.org/10.1086/261934 
Kaluza, B., Blecker, T., \& Bischof, C. (1999). Implications of digital convergence on strategic management. In S. B. Dahiya (Ed.), The Current State of Economic Science (pp. 2223-2249). Rohtak: Spellbound Publications.

Katz, M. L. (1996). Remarks on the Economic Implications of Convergence. Industrial and Corporate Change, 3, 1079-1095. https://doi.org/10.1093/icc/5.4.1079

Kenney, M., \& Pon B. (2011). Structuring the smartphone industry: is the mobile internet OS platform the key? Journal of Industry Competition and Trade, 11(3), 239-261. https://doi.org/10.1007/s10842-011-0105-6

Kim B., Lee J. D., \& Koh D. Y. (2005). Effects of consumer preferences on the convergence of mobile telecommunications devices. Applied $\quad$ Econonomics, 37 37(7), https://doi.org/10.1080/0003684042000337398

Kim, N., Lee, H., Kim, W., Lee, H., \& Suh, J. H. (2015). Dynamic patterns of industry convergence: Evidence from a large amount of unstructured data. Research Policy, 44, 1734-1748. https://doi.org/10.1016/j.respol.2015.02.001

Klepper, S. (1996). Entry, Exit, Growth and Innovation Over the Product Life Cycle. American Economic Review, 86(3), 562-583.

Klepper, S. (1997). Industry Life Cycles. Industrial and Corporate Change, 6(1), 145-181. https://doi.org/10.1093/icc/6.1.145

Klepper, S., \& Graddy, E. (1990). The Evolution of New Industries and the Determinants of Market Structure. Rand Journal of Economics, 21, 27-44. https://doi.org/10.2307/2555491

Klepper, S., \& Simons, K. L. (1996). Innovation and industry shakeouts. Business \& Economic History, 25(1), 81-89.

Koski, H., \& Kretschmer, T. (2007). Innovation and dominant design in mobile telephony. Industry and Innovation, 14(3), 305-324. https://doi.org/10.1080/13662710701369262

Lee, M., Lee, J., \& Cho, Y. (2009). How a convergence product affects related markets: The case of the mobile phone. ETRI Journal, 31(2), 215-224. https://doi.org/10.4218/etrij.09.0108.0574

Lee, S. M., Olson, D. L., \& Trimi, S. (2010). The impact of convergence on organizational innovation. Organizational Dynamics, 39(3), 218-225. https://doi.org/10.1016/j.orgdyn.2010.03.004

Lei, D. T. (2000). Industry evolution and competence development: the imperatives of technological convergence. International Journal of Technology Management, 19(7/8), 699-738. https://doi.org/10.1504/IJTM.2000.002848

Lind, J. (2005). Ubiquitous Convergence: Market Redefinitions Generated by Technological Change and the Industry Life Cycle. Paper for the DRUID Academy Winter Conference. Aalborg, Denmark.

Mueller, D. (1991). Entry, Exit and the Competitive Process. In P. Geroski, \& J. Schwalbach (Eds.), Entry and Market Contestability (pp. 1-22). Oxford: Basil Blackwell.

Nelson, R., \& Winter, S. (1982). An Evolutionary Theory of Economic Change. Cambridge MA: Harvard University Press.

Ono, R., \& Aoki, K. (1998). Convergence and new regulatory frameworks. Telecommunications Policy, 22(10), 817-838. https://doi.org/10.1016/S0308-5961(98)00064-0

Pennings, J. M., \& Puranam, P. (2001). Market Convergence \& Firm Strategy: New Directions for Theory and Research. Paper presented at the ECIS conference. The future of innovation studies, Eindhoven, the Netherlands, September 20-23.

Querbes-Revier, A. (2011). The strategic trade-offs for beneficial open innovation: the case of 'open source' consortia in mobile os development. Journal of Innovation Economics \& Management, 1(7), 109-130. https://doi.org/10.3917/jie.007.0109

Statista. (2019). The Smartphone Duopoly. Smartphone Market, May 20. Retrieved from https://cdn.statista.com/chart/3268/smartphone-os-market-share/

Stieglitz, N. (2003). Digital Dynamics and Types of Industry Convergence: The Evolution of the Handheld Computers Market. In F. Christensen, \& P. Maskell (Eds.), The Industrial Dynamics of the New Digital Economy (pp. 179-208). Cheltenham, UK-Northampton, MA: Edward Elgar.

Tushman, M. L., \& Anderson, P. (1986). Technological discontinuities and organizational environments. 
Administrative Science Quarterly, 31, 439-465. https://doi.org/10.2307/2392832

Utterback, J. M., \& Suarez, F. (1993). Innovation, Competition, and Industry Structure. Research Policy, 22(1), 1-21. https://doi.org/10.1016/0048-7333(93)90030-L

Vernon, R. (1966). International Investment and International Trade in the Product Life Cycle. Quarterly Journal of Economics, 80, 190-207. https://doi.org/10.2307/1880689

Weaver, B. (2007). Research proposal: industry convergence: driving forces, factors and consequences. Nordic Academy of Management Conference, 1-20.

West, J., \& Mace, M. (2010). Browsing as the killer app explaining the rapid success of Apple's iPhone. Telecommunication Policy, 34(5), 270-286. https://doi.org/10.1016/j.telpol.2009.12.002

Wirtz, B. W. (2001). Reconfiguration of value chains in converging media and communications markets. Long Range Planning, 34, 489-506. https://doi.org/10.1016/S0024-6301(01)00066-8

Yoffie, D. B. (1997). Introduction: CHESS and competing in the age of digital convergence. In D. Yoffie (Ed.), Competing in the Age of Digital Convergence (pp. 1-35). Boston, MA: Harvard Business School Press.

\section{Notes}

Note 1. The companies that produced at least two different smartphone models in two different years were considered.

Note 2. However, it should be highlighted that, as estimated by Counterpoint Research (2019), from 2019 the feature phone market is forecast to generate a slight inversion of sales, especially in relation to the increase in demand for first purchase of mobile phones in emerging markets, such as India in particular.

\section{Copyrights}

Copyright for this article is retained by the author(s), with first publication rights granted to the journal.

This is an open-access article distributed under the terms and conditions of the Creative Commons Attribution license (http://creativecommons.org/licenses/by/4.0/). 